\section{Nature Observations From The Pupils of Omand School, Kinistino, Saskatchewan}

The pupils at Omand School have a bird feeding station. Linda Beaulieu tells about the trouble they are having keeping the food frcm blowing away and the snow from covering it. Perhaps some of our readers can tell how they solved this problem. Brenda Gudelot writes about building a bird feeding tray at home: "One day, dadidy, my sister and I were talking about how to help birds when they can't find food to feed their brabies or themselves, so we decided to build a feeding tray. We got a short board and some nails and three lids off some old cans. We put the lids on the board and hammered the nails through the lids and into the board. After we had finished hammering the nails, we put some crumbs in the lids. We set it outside and not too soon after, we saw about four Black-capped Chickadees eating the crumbs."

A skunk visited the farmyard when Barry Warbis was tying up the cows and got shot as a result. Another casuality of the shotgun is an eagle which Marlene Hills wrote about: "The eagle had a short, curved bill. Its claws were sharp and pointed. It was black and brown in color. The eagle's wings whe $n$ stretched out, were about six feet wide. I read a lot about birds, but I still do not know what kind of eagle it was. It is very, very unusual for an eagle to be in this part of the country."

From Marlene's description the eagle is probably an immature Bald Eagle. The adult Bald Eagle has a snowy white head and tail. The immature is totally dark brown and black. Golden Eagles are generally a dark brown color with white marks underneath the wing and a faint white strip across the tail. Goldenbrown feathers on the back of the neck give the Golden Eagle its name.

Because of their rarity and beauty every effort should be made to protect these birds. Besides this, it is against the law to shoot them. The Museum is interested in receiving reports about eagles which are sighted in the province.

While on a nature hike with the rest of the class, Gary Hills made the following observations: "First we saw birds and animals doing different things but the best thing I liked was the Killdeer and its nest. The Killdeer is about ten inches long. Its legs are long and straight. The nest is just a little hole in the ground. The Killdeer's eggs are a darkish white with black spots on them.

"When we came near, the mither Killdeer limped away as if she was hurt and trying to lead us away. When we went away the mother Killdeer waited for a couple of minutes and then she flew back to the nest."

Beverly Beaulieu was surprised to see what a cat was doing with the mouse it caught. She peeked into the cellar and found the cat playing with the mouse.

A letter about tame hawks comes from Gail Gudeloit. The haiwks were captured when young and were fed meat scraps, bread and water. "Then one day while Brendia and I were feeding chicks," Glail writes, "we heard a noise outside. We ran outzide and saw one of the hawks trying to kill a chick. After we scared the h'awk away daddy came out with a sling shot and was going to scare him so he shot and hit the edge of the hawk's wing but never hurt him. Then a few weeks later the hawks flew away and we haven't seen them since."
BULL SNAKE by Doreen Jasper, age 15 , Regina, drawn from a captive snake at the Saskatchewan Museum of Natural History. 